\title{
KEEFEKTIFAN PBL DITINJAU DARI KEMAMPUAN BERPIKIR KRITIS DAN KREATIF MATEMATIS, SERTA SELF-ESTEEM SISWA SMP
}

\author{
Nurina Happy ${ }^{1)}$, Djamilah Bondan Widjajanti ${ }^{2)}$ \\ Universitas PGRI Semarang ${ }^{1)}$, Universitas Negeri Yogyakarta ${ }^{2)}$ \\ nurinahappy@gmail.com ${ }^{1)}$,dj_bondan@yahoo.com ${ }^{2)}$
}

\begin{abstract}
Abstrak
Penelitian ini bertujuan untuk mendeskripsikan: (1) keefektifan problem-based learning (PBL) ditinjau dari (a) kemampuan berpikir kritis matematis, (b) kemampuan berpikir kreatif matematis, dan (c) self-esteem; serta (2) perbandingan keefektifan problem-based learning dan pembelajaran konvensional ditinjau dari (a) kemampuan berpikir kritis matematis, (b) kemampuan berpikir kreatif matematis, dan (c) self-esteem. Penelitian ini merupakan penelitian eksperimen semu. Pengumpulan data menggunakan metode pemberian pretest dan posttest kemampuan berpikir kritis dan kreatif matematis, serta pemberian angket self-esteem sebelum dan sesudah perlakuan. Uji statistik yang digunakan adalah uji proporsi dan uji selisih antara dua proporsi. Hasil penelitian menunjukkan pada taraf signifikansi 5\% dapat disimpulkan bahwa (1) problem-based learning efektif ditinjau dari kemampuan berpikir kreatif matematis, tetapi tidak efektif ditinjau dari kemampuan berpikir kritis matematis dan self-esteem; serta (2) problem-based learning lebih efektif dibandingkan pembelajaran konvensional ditinjau dari (a) kemampuan berpikir kritis matematis, (b) kemampuan berpikir kreatif matematis, dan (c) self-esteem.
\end{abstract}

Kata kunci: problem-based learning, berpikir kritis, berpikir kreatif, self-esteem

\section{THE EFFECTIVENESS OF PBL ON MATHEMATICAL CRITICAL AND CREATIVE THINKING SKILLS, AND SELF-ESTEEM OF JUNIOR HIGH SCHOOL STUDENTS}

\begin{abstract}
This study aims to describe: (1) the effectiveness of problem-based learning (PBL) on (a) mathematical critical thinking skill, (b) mathematical creative thinking skill, and (c) self-esteem; and (2) the comparison in the effectiveness between problem-based learning and conventional learning on (a) mathematical critical thinking skill, (b) mathematical creative thinking skill, and (c) self-esteem. This study was a quasi-experiment.The data were collected through a mathematical critical and creative thinking skills tests, student's self-esteem questionnaire. The data were analyzed descriptively and statistically. The statistic tests were used test on one proportion and tests on two proportion. The results of the study that at the significance level of 5\%, it can be inferred that (1) problem-based earning is effective on mathematical creative thinking skill, but it's not effective on mathematical critical thinking skill and self-esteem; and (2) problem-based learning is more effective than conventional learning on (a) mathematical critical thinking skill, (b) mathematical creative thinking skill, and (c) self-esteem.
\end{abstract}

Keywords: problem-based learnng, critical thinking skill, creative thinking skill, self-esteem 


\section{PENDAHULUAN}

Masalah-masalah yang dihadapi seseorang akan menjadi lebih kompleks seiring perkembangan usia dan lingkungan sosialnya. Untuk dapat survive, seseorang perlu memiliki kemampuan berpikir kritis dan kreatif, karena dengan memiliki kemampuan tersebut ia akan lebih mudah menghadapi masalah dan menyelesaikannya. Kemampuan berpikir kritis dan kreatif memungkinkan seseorang mempelajari masalah yang dihadapi secara sistematis, menghadapi berbagai tantangan dengan cara yang terorganisir, merumuskan pertanyaan-pertanyaan yang inovatif, dan merancang solusi-solusi yang orisinal (Johnson, 2002, p.100). Selain itu, berpikir secara kritis dan kreatif dapat mengembangkan diri seseorang dalam mengambil keputusan atau memberikan penilaian terhadap suatu hal sehingga dapat menyelesaikan suatu masalah (Hassoubah, 2008, p.13).

Meskipun memiliki kemampuan berpikir kritis dan kreatif sangat penting, pada kenyataannya kedua kemampuan tersebut belum dikuasai dengan baik oleh siswa Indonesia. Hal tersebut dapat dilihat pada hasil TIMSS 2011 pada domain proses kognitif (konten) yang disajikan pada tabel 1 berikut.

Tabel 1. Persentase Rata-Rata Jawaban Benar Siswa Indonesia Dibandingkan dengan Siswa Internasional pada Domain Proses Kognitif dalam TIMSS 2011

\begin{tabular}{ccc}
\hline $\begin{array}{c}\text { Aspek pada } \\
\text { Domain Proses } \\
\text { Kognitif }\end{array}$ & \multicolumn{2}{c}{$\begin{array}{c}\text { Rata-rata Jawaban Benar } \\
\text { (\%) }\end{array}$} \\
\cline { 2 - 3 } & Indonesia & Internasional \\
\hline Pengetahuan & 31 & 49 \\
Aplikasi & 23 & 39 \\
Penalaran & 17 & 30 \\
\hline Sumber: Mullis, et al. (2012, p.462)
\end{tabular}

Sumber: Mullis, et al. (2012, p.462)

Berdasarkan tabel 1 di atas, terlihat bahwa kemampuan siswa Indonesia yang paling lemah pada domain proses kognitif adalah penalaran. Rata-rata jawaban benar pada kemampuan penalaran siswa Indonesia hanya $17 \%$ atau $13 \%$ lebih rendah dibandingkan rata-rata siswa Internasional. Selain itu, kemampuan penalaran siswa secara Internasional juga lebih lemah dibandingkan pengetahuan dan aplikasi.

Adanya fakta hasil TIMSS 2011 pada domain proses kognitif bahwa kemampuan penalaran siswa yang masih lemah menjadi indikasi masih lemahnya kemampuan berpikir kritis dan kreatif. Hal tersebut karena penalaran menurut Krulik \& Rudnick (1995, p.2) mencakup ber- pikir dasar (basic thinking), berpikir kritis (critical thinking), dan berpikir kreatif (creative thinking). Oleh karena itu, hasil TIMSS 2011 dapat dijadikan dasar bahwa kemampuan berpikir kritis dan kreatif siswa kelas VIII memerlukan perhatian khusus.

Lemahnya kemampuan berpikir kritis dan kreatif matematis siswa dapat disebabkan oleh beberapa faktor. Salah satu diantaranya adalah proses pembelajaran yang dilaksanakan. Pembelajaran matematika haruslah melibatkan siswa secara aktif serta memfasilitasi siswa untuk dapat menggunakan kemampuan berpikir kritis dan kreatifnya. Seperti yang diungkapkan oleh Johnson (2002, pp.100-101) bahwa jika siswa diberi kesempatan untuk melatih kemampuan berpikirnya, nantinya akan terbentuk suatu kebiasaan untuk dapat membedakan antara benar dan tidak benar, dugaan dan kenyataan, fakta dan opini, serta pengetahuan dan keyakinan. Dengan demikian siswa secara alami akan dapat membangun argumen yang didasari bukti logis dan terpercaya. Selain itu, siswa juga secara alami akan berpikir secara kreatif. Hal tersebut ditunjukkan dengan terbentuknya kebiasaan untuk membuat keterkaitan antara hal-hal yang berbeda, melihat kemungkinan yang tidak terduga, dan berpikir dengan cara yang baru pada masalah-masalah yang sudah biasa dihadapi.

Di samping itu, sudah menjadi suatu kewajiban bagi guru untuk dapat merancang pembelajaran yang interaktif, inspiratif, menyenangkan, menantang, dan memotivasi siswa untuk berpartisipasi aktif sesuai dengan Permendiknas No 41 Tahun 2007 tentang Standar Proses untuk Pendidikan Dasar dan Menengah. Pembelajaran yang dilaksanakan juga harus memberikan ruang yang cukup bagi prakarsa, kreativitas, dan kemandirian sesuai dengan bakat, minat, dan perkembangan fisik serta psikologis siswa (Depdiknas, 2007). Pembelajaran di kelas juga akan lebih efektif jika guru dapat mengombinasikan pendekatan yang tidak hanya mengembangkan aspek kognitif saja, tetapi juga aspek afektif, khususnya self-esteem (harga diri) siswa.

Self-esteem menjadi perhatian yang sangat penting karena menurut Young \& Hoffmann (2004, p.87) self-esteem berhubungan dengan sejumlah faktor kehidupan, salah satu diantaranya kesuksesan siswa di sekolah. Lawrence (2006, pp.8-9) menambahkan siswa dengan selfesteem tinggi cenderung percaya diri dalam situasi sosial yang dihadapi dan percaya diri dalam menangani tugas-tugas yang diberikan 
oleh guru. Selain itu, siswa dengan self-esteem tinggi tersebut akan mempertahankan rasa keingintahuannya secara alami dalam belajar serta memiliki semangat dan antusias ketika menghadapi tantangan baru. Sebaliknya, siswa dengan self-esteem rendah justru menghindari situasi dimana situasi tersebut berpotensi membuat dirinya merasa malu dihadapan orang lain. Siswa dengan self-esteem rendah cenderung lebih memilih dihukum atau mungkin dipandang sebagai seorang jagoan oleh teman-temannya dibandingkan terlihat bodoh.

Namun, pada kenyataannya self-esteem siswa kelas VIII di beberapa sekolah di Bantul masih perlu ditingkatkan. Hal tersebut dapat dilihat dari hasil angket self-esteem dengan menggunakan "Coopersmith Self-Esteem Inventory" (1996, pp.2-3). Hasil angket dapat dilihat pada tabel 2 berikut.

Tabel 2. Sebaran Hasil Angket Self-Esteem Dikelompokkan Berdasarkan Kategori Sangat Rendah (SR), Rendah (R), Sedang (S), Tinggi

(T), dan Sangat Tinggi (ST)

\begin{tabular}{lccccc}
\hline \multirow{2}{*}{ Nama Sekolah } & \multicolumn{5}{c}{ Kategori } \\
\cline { 2 - 6 } & SR & R & S & T & ST \\
\hline SMP 4 Pandak & 6 & 9 & 3 & 0 & 0 \\
SMP 2 Imogiri & 3 & 16 & 10 & 0 & 0 \\
SMP 3 Imogiri & 2 & 12 & 9 & 1 & 0 \\
SMP 4 Banguntapan & 1 & 7 & 14 & 3 & 0 \\
Jumlah & 12 & 44 & 36 & 4 & 0 \\
\hline
\end{tabular}

Dari tabel 2 tersebut dapat diketahui bahwa dari keempat sekolah hanya terdapat 4 siswa yang memiliki self-esteem dengan kategori tinggi. Mayoritas siswa memiliki self-esteem dengan kategori rendah. Bahkan, terdapat 12 siswa yang memiliki self-esteem dengan kategori sangat rendah.

Berdasarkan uraian-uraian yang telah diungkapkan dapat diambil benang merah bahwa sangat penting untuk dapat merancang dan melaksanakan suatu pembelajaran yang dapat memfasilitasi kemampuan berpikir kritis dan kreatif matematis, serta self-esteem siswa. Salah satu alternatif yang dapat digunakan dalam proses pembelajarannya adalah menerapkan problem-based learning.

Problem-based learning adalah suatu model pembelajaran yang dirancang dan dikembangkan untuk mengembangkan kemampuan peserta didik memecahkan masalah. Problembased learning dipilih karena (1) menyediakan masalah yang dekat dengan kehidupan nyata dan mungkin terjadi dalam kehidupan nyata, (2) mendorong siswa terlibat dalam kegiatan pem- belajaran, (3) mendorong penggunaan berbagai pendekatan, (4) memberi kesempatan siswa membuat pilihan bagaimana dan apa yang akan dipelajarinya, (5) mendorong pembelajaran kolaboratif, dan (6) membantu mencapai pendidikan yang berkualitas (Delisle, 1997, pp.8-13).

Keunggulan problem-based learning dalam pengembangan kemampuan berpikir kritis dan kreatif matematis didukung adanya penelitian sebelumnya yang dilakukan oleh Sugandi (2011) bahwa pada taraf signifikansi 5\% pembelajaran berbasis masalah dengan setting kooperatif jigsaw lebih efektif dari pembelajaran konvensional ditinjau dari kemampuan berpikir kritis dan kreatif matematis. Hasil penelitian Noer (2009) juga mengungkapkan bahwa terdapat perbedaan yang signifikan antara kualitas peningkatan kemampuan berpikir kritis matematis siswa yang mendapatkan pembelajaran matematika dengan menggunakan pembelajaran berbasis masalah dan siswa yang mendapat pembelajaran konvensional. Hasil penelitian Khoiri (2013) mengungkapkan bahwa rata-rata hasil tes kemampuan berpikir kreatif siswa kelas problem-based learning berbantuan multimedia lebih baik daripada rata-rata peningkatan kemampuan berpikir kreatif siswa kelas konvensional. Bahkan hasil penelitian Nugroho, Chotim, \& Dwijanto (2013) mengungkapkan bahwa problem-based learning berbantuan CD pembelajaran lebih efektif untuk mengembangkan kemampuan berpikir kreatif matematis dibandingkan pendekatan konvensional.

Keunggulan problem-based learning dalam mengakomodasi self-esteem siswa didukung oleh salah satu hasil penelitian Amsikan (2009) bahwa problem-based learning lebih efektif dari model cooperative learning tipe jigsaw ditinjau dari aspek self-concept siswa. Penelitian ini relevan karena menurut Plummer (2005, p.13) self-esteem diindikasikan dengan adanya perbedaan antara self-concept (apa yang dirasakan) dan ideal-self (ideal diri). Hasil penelitian lain dilakukan oleh Fadillah (2012) bahwa selfesteem siswa pada matematika dengan pendekatan open-ended lebih baik dari self-esteem siswa dengan pembelajaran biasa. Meskipun pada penelitian ini Fadillah tidak menggunakan problem-based learning, tetapi penelitian ini masih relevan karena open-ended memiliki persamaan dengan problem-based learning diantaranya masalah terbuka sehingga memungkinkan lebih dari satu cara penyelesaian atau solusi dari masalah. Dengan masalah yang tidak ada satu jawaban benar memberi kesempatan 
siswa untuk berhasil dalam menyelesaikan masalah matematika yang dihadapi.

Berdasarkan uraian tersebut rumusan masalah dari penelitian ini adalah, (1) Apakah problem-based learning efektif ditinjau dari (a) kemampuan berpikir kritis matematis, (b) kemampuan berpikir kreatif matematis, dan (c) self-esteem?: (2) Dibandingkan dengan pembelajaran konvensional, apakah problem-based learning lebih efektif ditinjau dari (a) kemampuan berpikir kritis matematis, (b) kemampuan berpikir kreatif matematis, dan (c) self-esteem?

Sesuai dengan rumusan masalah tersebut, maka tujuan penelitian ini adalah untuk mendeskripsikan: (1) Keefektifan problem-based learning ditinjau dari (a) kemampuan berpikir kritis matematis, (c) kemampuan berpikir kreatif matematis, dan (c) self-esteem; (2) Perbandingan keefektifan problem-based learning dan pembelajaran konvensional ditinjau dari (a) kemampuan berpikir kritis matematis, (b) kemampuan berpikir kreatif matematis, dan (c) self-esteem.

Manfaat dari penelitian ini secara teori dapat memberikan sumbangan berupa kajian tentang keefektifan pembelajaran problem-based learning ditinjau dari kemampuan berpikir kritis dan kreatif matematis, serta self-esteem siswa, sedangkan secara praktis dapat digunakan sebagai acuan dalam mendesain pembelajaran sehingga pembelajaran lebih bervariasi dan menyenangkan.

\section{METODE PENELITIAN}

\section{Jenis Penelitian}

Penelitian ini merupakan penelitian eksperimen semu (quasi experiment).

\section{Waktu dan Tempat Penelitian}

Penelitian dilaksanakan di SMP Negeri 2 Imogiri pada tanggal 2 April 2013 sampai 8 Juni 2013.

\section{Populasi-Sampel Penelitian}

Populasi dalam penelitian ini adalah seluruh siswa kelas VIII SMP Negeri 2 Imogiri Bantul. Sampel penelitian adalah siswa kelas VIIID sebagai kelas eksperimen dan siswa kelas VIIIC sebagai kelas kontrol. Sampel dipilih dengan pemilihan acak melalui pengundian.

\section{Prosedur}

Desain penelitian dalam penelitian adalah sebagai berikut.

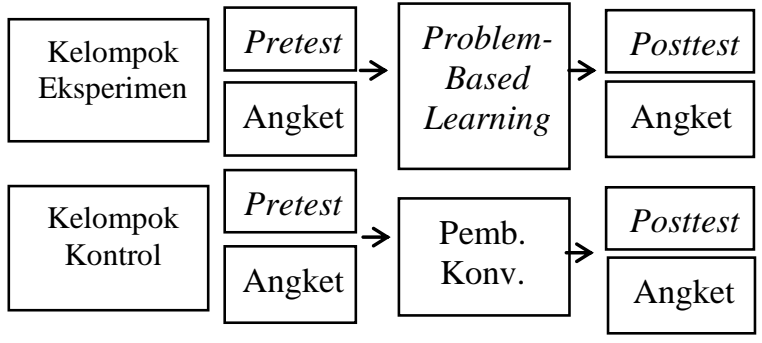

Gambar 1. Desain Penelitian

\section{Data, Intrumen, dan Teknik Pengumpulan Data}

Data dalam penelitian ini dikumpulkan melalui pemberian pretest dan posttest kemampuan berpikir kritis dan kreatif matematis, serta pemberian angket self-esteem sebelum dan sesudah perlakuan.

\section{Validitas dan Reliabilitas Instrumen}

Dari segi validitas isi, intrumen tes dan angket layak digunakan menurut reviewer. Dari segi validitas kontruk, berdasarkan hasil Confirmatory Factor Analysis (CFA) pada angket selfesteem diperoleh bahwa hasil uji secara keseluruhan menyatakan model fit danhasil uji pada masing-masing parameter estimasi juga fit.

Reliabilitas tes kemampuan berpikir kritis matematis adalah 0,78 dengan Standard Error Measurement (SEM) sebesar 1,06. Reliabilitas tes kemampuan berpikir kreatif matematis adalah 0,73 dengan nilai SEM sebesar 1,07. Reliabilitas angket self-esteem adalah 0,83 dengan SEM sebesar 4,33.

\section{Teknik Analisis Data}

Teknik analisis data terdiri dari analisis desktiptif dan analisis statistik. Secara deskriptif, data dijabarkan berdasarkan rata-rata, standar deviasi, skor maksimum, dan skor minimum. Analisis secara statistik menggunakan uji proporsi dan uji selisih antara dua proporsi. Data yang digunakan dalam analisis statistik adalah data posttest. Uji proporsi digunakan untuk menganalisis apakah problem-based learning efektif ditinjau dari kemampuan berpikir kritis matematis, kemampuan berpikir kreatif matematis, dan self-esteem siswa. Hipotesis yang akan diuji adalah sebagai berikut.

$$
\begin{aligned}
& H_{01}: \pi_{1} \leq 0,79 \\
& H_{11}: \pi_{1}>0,79 \\
& H_{02}: \pi_{1} \leq 0,79 \\
& H_{12}: \pi_{1}>0,79
\end{aligned}
$$


$H_{03}: \pi_{1} \leq 0,79$

$H_{13}: \pi_{1}>0,79$

dengan,

$H_{i 1}$ : menyatakan hipotesis untuk kemampuan berpikir kritis matematis.

$H_{i 2}$ : menyatakan hipotesis untuk kemampuan berpikir kreatif matematis.

$H_{i 3}$ : menyatakan hipotesis untuk self-esteem.

Rumus yang digunakan dalam uji proporsi adalah sebagai berikut.

$$
z=\frac{x-n p_{0}}{\sqrt{n p_{0} q_{0}}}=\frac{\hat{p}-p_{0}}{\sqrt{p_{0} q_{0} / n}}
$$

(Walpole, et al., 2012, p.362)

Keterangan:

$\hat{p}$ s peluang banyaknya siswa berhasil $\left(\frac{x}{n}\right)$

$x$ : banyaknya siswa yang berhasil

$p_{0}$ : nilai yang dihipotesiskan

$q_{0}=1-p_{0}$

n: banyaknya siswa

Wilayah kritis yang digunakan adalah $z>z_{\alpha}$ sehingga $H_{0 j}(j=1,2,3)$ ditolak jika $z$ jatuh ke dalam wilayah kritis.

Uji selisih antara dua proporsi digunakan untuk mengetahui perbandingan keefektifan problem-based learning dan pembelajaran konvensional ditinjau dari kemampuan berpikir kritis matematis, kemampuan berpikir kreatif matematis, dan self-esteem siswa. Hipotesis yang akan diuji adalah sebagai berikut.

$$
\begin{aligned}
& H_{01}: \pi_{1} \leq \pi_{2} \\
& H_{11}: \pi_{1}>\pi_{2} \\
& H_{02}: \pi_{1} \leq \pi_{2} \\
& H_{12}: \pi_{1}>\pi_{2} \\
& H_{03}: \pi_{1} \leq \pi_{2} \\
& H_{13}: \pi_{1}>\pi_{2}
\end{aligned}
$$
berikut.

Hipotesis tersebut diuji dengan rumus

$$
z=\frac{\widehat{p_{1}}-\widehat{p_{2}}}{\sqrt{\hat{p} \hat{q}\left[\frac{1}{n_{1}}+\frac{1}{n_{2}}\right]}}
$$

(Walpole, et al., 2012, p.364)
Keterangan:

$\widehat{p_{1}}$ : (peluang keberhasilan kelas eksperimen $)=\left(\frac{x_{1}}{n_{1}}\right)$

$\widehat{p_{2}}$ : (peluang keberhasilan kelas kontrol $)=\left(\frac{x_{2}}{n_{2}}\right)$

$\hat{p}$ : (pooled estimate of the proportion $p$ ) $=\frac{x_{1}+x_{2}}{n_{1}+n_{1}}$

$\widehat{q}$ (pooled estimate of the proportion $q$ ) $=1-\hat{p}$

$n_{1}$ : banyaknya siswa di kelas eksperimen $n_{2}$ : banyaknya siswa di kelas kontrol

Wilayah kritis yang digunakan adalah $z>z_{\alpha}$ sehingga $H_{0 j}(j=1,2,3)$ ditolak jika $z$ jatuh ke dalam wilayah kritis.

HASIL PENELITIAN DAN PEMBAHASAN

Keefektifan Problem-Based Learning Ditinjau dari Kemampuan Berpikir Kritis Matematis, Kemampuan Berpikir Kreatif Matematis, dan Self-Esteem

Data hasil tes kemampuan berpikir kritis matematis disajikan pada tabel 3 berikut.

Tabel 3. Data Kemampuan Berpikir Kritis Matematis

\begin{tabular}{lcccc}
\hline \multirow{2}{*}{ Nilai } & \multicolumn{2}{c}{$\begin{array}{c}\text { Kelas } \\
\text { Eksperimen }\end{array}$} & \multicolumn{2}{c}{ Kelas Kontrol } \\
\cline { 2 - 5 } & Pretest & Posttest & Pretest & Posttest \\
\hline Rata-rata & 9,73 & 16,07 & 9,60 & 11,47 \\
Standar deviasi & 1,84 & 3,03 & 1,81 & 1,91 \\
\hline
\end{tabular}

Dari tabel 3 di atas dapat diketahui bahwa nilai rata-rata dan standar deviasi sebelum perlakuan pada kelas eksperimen dan kelas kontrol relatif sama. Namun, nilai rata-rata setelah perlakuan menunjukkan bahwa kelas ekperimen lebih tinggi daripada kelas kontrol, yaitu selisih $19,17 \%$. Kenaikan nilai rata-rata kemampuan berpikir kritis matematis sebelum dan setelah perlakuan terjadi di kedua kelas, yaitu $26.39 \%$ pada kelas eksperimen dan $7,78 \%$ pada kelas kontrol.

Proporsi ketuntasan siswa pada kemampuan berpikir kritis matematis disajikan pada tabel 4 berikut.

Tabel 4. Proporsi Ketuntasan Siswa pada Kemampuan Berpikir Kritis Matematis

\begin{tabular}{ccccc}
\hline \multirow{2}{*}{ Proporsi } & \multicolumn{2}{c}{ Kelas Eksperimen } & \multicolumn{2}{c}{ Kelas Kontrol } \\
\cline { 2 - 5 } & Pretest & Posttest & Pretest & Posttest \\
\hline Tuntas & $3,33 \%$ & $70 \%$ & $0 \%$ & $3,33 \%$ \\
Tidak & $96,67 \%$ & $30 \%$ & $100 \%$ & $96,67 \%$ \\
Tuntas & & & & \\
\hline
\end{tabular}


Tabel 4 tersebut menunjukkan bahwa setelah adanya perlakuan proporsi siswa tuntas pada kelas eksperimen naik sebesar 66,67\%. Meskipun demikian, proporsi ketuntasan siswa pada posttest di kelas eksperimen belum memenuhi kriteria yang ditetapkan peneliti, yaitu lebih dari $79 \%$.

Hasil uji hipotesis diperoleh nilai $z$ hitung sebesar $-1,21$ dimana nilai tersebut lebih kecil dari nilai $z_{0,05}=1,645$ sehingga $H_{0}$ tidak dapat ditolak. Oleh sebab itu pada taraf signifikansi 5\% dapat dikatakan bahwa problem-based learning tidak efektif ditinjau dari kemampuan berpikir kritis matematis.

Hasil tersebut belum sesuai dengan teori Watson \& Groh (2001, pp.20-21) bahwa problem-based learning menjamin siswa akan dapat melakukan beberapa hal, diantaranya belajar berpikir kritis untuk menyelesaikan masalah.

Tahap-tahap problem-based learning secara teori mengakomodasi adanya pengembangan kemampuan berpikir kritis matematis melalui masalah sebagai perhatian utama. Meskipun demikian, pada kenyataannya siswa masih mengalami kesulitan untuk memahami masalah yang dihadapi dan menyelesaikannya pada beberapa pertemuan. Selain itu, masalah yang disajikan pada beberapa pertemuan lebih menonjolkan aspek focus, reason, dan inference sehingga aspek situation, clatiry, dan overview menjadi lebih lemah.

Data hasil tes kemampuan berpikir kreatif matematis disajikan pada tabel 5 berikut.

Tabel 5. Data Kemampuan Berpikir Kreatif Matematis

\begin{tabular}{lcccc}
\hline \multirow{2}{*}{ Nilai } & \multicolumn{2}{c}{ Kelas Eksperimen } & \multicolumn{2}{c}{ Kelas Kontrol } \\
\cline { 2 - 5 } & Pretest & Posttest & Pretest & Posttest \\
\hline Rata-rata & 7,17 & 11,97 & 7,00 & 8,13 \\
Standar deviasi & 1,76 & 1,94 & 1,76 & 2,49 \\
\hline
\end{tabular}

Dari tabel 5 diketahui bahwa nilai ratarata kemampuan berpikir kreatif matematis sebelum perlakuan pada kelas eksperimen dan kelas kontrol relatif sama. Standar deviasi sebelum perlakuan juga relatif sama pada kedua kelas. Kenaikan rata-rata kemampuan berpikir kreatif matematis sebelum dan sesudah perlakuan pada kelas eksperimen adalah 30\%. Setelah adanya perlakuan nilai rata-rata kemampuan berpikir kreatif matematis kelas eksperimen menjadi lebih tinggi 23,963\% dibandingkan kelas kontrol.
Proporsi ketuntasan siswa pada kemampuan berpikir kreatif matematis disajikan pada tabel 6 berikut.

Tabel 6. Proporsi Ketuntasan Siswa pada Kemampuan Berpikir Kreatif Matematis

\begin{tabular}{ccccc}
\hline \multirow{2}{*}{ Proporsi } & \multicolumn{2}{c}{ Kelas } & \multicolumn{2}{c}{ Kelas Kontrol } \\
\cline { 2 - 5 } & Pretest & Posttest & Pretest & Posttest \\
\hline Tuntas & $13,33 \%$ & $93,33 \%$ & $6,67 \%$ & $23,33 \%$ \\
Tidak & $86,67 \%$ & $6,67 \%$ & $93,33 \%$ & $76,67 \%$ \\
Tuntas & & & & \\
\hline
\end{tabular}

Tabel 6 tersebut menunjukkan bahwa setelah adanya perlakuan proporsi siswa tuntas pada kelas eksperimen naik sebesar $80 \%$. Selain itu, proporsi ketuntasan siswa pada posttest di kelas eksperimen yang mencapai $93,33 \%$ menunjukkan bahwa nilai tersebut memenuhi kriteria yang ditetapkan peneliti, yaitu lebih dari $79 \%$.

Hasil uji hipotesis diperoleh nilai $z$ hitung sebesar 1,93 dimana nilai tersebut lebih kecil dari nilai $z_{0,05}=1,645$ sehingga $H_{0}$ dapat ditolak. Oleh sebab itu pada taraf signifikansi 5\% dapat dikatakan bahwa problem-based learning efektif ditinjau dari kemampuan berpikir kreatif matematis.

Hasil tersebut mendukung pendapat Arends \& Kilcher (2010, p.328) bahwa problem-based learning berkontribusi dalam meningkatkan kemampuan berpikir kreatif siswa. Hasil tersebut juga mendukung pendapat Watson \& Groh (2001, p.21) bahwa problembased learning menjamin siswanya akan dapat memperluas pemahaman dan mengapresiasi kreativitas alaminya.

Kemampuan berpikir kreatif dalam pelaksanaannya dengan problem-based learning banyak dilatih pada tahap visiting the problem dan revisiting the problem. Pada tahap ini siswa mengekplorasi cara atau solusi lain seperti yang telah diperoleh sebelumnya. Hal tersebut didukung oleh tersedianya beberapa masalah yang memang menuntut siswa menggunakan beberapa cara atau menyediakan beberapa solusi dalam rangka memecahkan masalah. Dalam memecahkan masalah tidak hanya kemampuan berpikir kritis yang dilatih, tetapi siswa juga menggunakan kemampuan berpikir kreatifnya. Hal tersebut sesuai dengan pendapat Ho (2004, p.102) bahwa adanya masalah yang ill-structured, siswa dituntut untuk aktif menggunakan kemampuan berpikir kritis dan kreatifnya dalam memecahkan masalah. 
Tahap lain yang menyediakan banyak aktivitas yang mengasah kemampuan berpikir kreatif adalah producing a product or a performance. Dalam tahap ini siswa diminta untuk mempersiapkan hasil diskusi kelompok yang telah dilakukan sebelumnya. Pada beberapa pertemuan, siswa diminta untuk menghasilkan sebuah karya yang membutuhkan kreativitas dengan memadukan matematika dan seni. Contoh karya yang perlu dibuat siswa adalah pembuatan diorama dan desain kemasan sereal. Kegiatan tersebut sesuai dengan teori terkait kriteria masalah dalam problem-based learning yang diungkapkan oleh Delisle (1997, pp.21-24) yaitu masalah dapat mengintegrasikan beberapa mata pelajaran yang berkaitan dengan topik yang dipelajari.

Data hasil angket self-esteem disajikan pada tabel 7 berikut.

Tabel 7. Data Self-Esteem

\begin{tabular}{lcccc}
\hline \multirow{2}{*}{ Nilai } & \multicolumn{2}{c}{ Kelas Eksperimen } & \multicolumn{2}{c}{ Kelas Kontrol } \\
\cline { 2 - 5 } & Pretest & Posttest & Pretest & Posttest \\
\hline Rata-rata & 90,50 & 113,20 & 90,57 & 106,57 \\
Standar deviasi & 9,59 & 8,80 & 9,52 & 9,66 \\
\hline
\end{tabular}

Dari tabel 7 tersebut data diketahui bahwa rata-rata skor sebelum perlakuan dan setelah perlakuan pada kedua kelas relatif sama dengan standar deviasi yang relatif sama pula. Setelah adanya perlakuan terlihat bahwa skor selfesteem siswa pada kelas eksperimen lebih tinggi 4,14\% dibandingkan kelas kontrol. Pada kelas eksperimen dan kelas kontrol sama-sama terjadi peningkatan rata-rata skor self-esteem dari sebelum perlakuan ke setelah adanya perlakuan. Peningkatan rata-rata skor self-esteem pada kelas eksperimen adalah $14,19 \%$, sedangkan pada kelas kontrol adalah 10\%. Apabila dilihat dari standar deviasinya, kelas kontrol memiliki standar deviasi yang lebih tinggi 0,86 dari kelas eksperimen setelah adanya perlakuan. Proporsi ketuntasan siswa pada kemampuan berpikir kritis matematis disajikan pada tabel 8 berikut.

Tabel 8. Proporsi Ketuntasan Siswa pada Kemampuan Berpikir Kritis Matematis

\begin{tabular}{ccccc}
\hline \multirow{2}{*}{ Proporsi } & \multicolumn{2}{c}{$\begin{array}{c}\text { Kelas } \\
\text { Eksperimen }\end{array}$} & \multicolumn{2}{c}{ Kelas Kontrol } \\
\cline { 2 - 5 } & Pretest & Posttest & Pretest & Posttest \\
\hline Tuntas & $3,33 \%$ & $76,67 \%$ & $3,33 \%$ & $36,67 \%$ \\
Tidak & $96,67 \%$ & $23,33 \%$ & $96,67 \%$ & $63,33 \%$ \\
Tuntas & & & & \\
\hline
\end{tabular}

Tabel 8 tersebut menunjukkan bahwa setelah adanya perlakuan proporsi siswa tuntas pada kelas eksperimen naik sebesar 73,34\%. Meskipun demikian, proporsi siswa tuntas pada posttest kelas eksperimen belum memenuhi kriteria.

Hasil uji hipotesis diperoleh nilai $z$ hitung sebesar $-0,31$ dimana nilai tersebut lebih kecil dari nilai $z_{0,05}=1,645$ sehingga $H_{0}$ tidak dapat ditolak. Oleh sebab itu pada taraf signifikansi 5\% dapat dikatakan bahwa problem-based learning tidak efektif ditinjau dari self-esteem.

Hasil tersebut belum sesuai dengan hasil penelitian Amsikan (2009) bahwa problembased learning efektif ditinjau dari self-concept siswa. Dalam pelaksanaan pembelajaran yang dilakukan peneliti menggabungkan antara teori problem-based learning dan beberapa aktivitas yang dapat melatih self-esteem seperti yang disarankan oleh Lawrence (2006, pp.87-93). Kegiatan tersebut diantaranya mendiskusikan kesuksesan yang diraih oleh seseorang, mengungkapkan emosi yang dimiliki siswa, mengingat kejadian membahagiakan yang pernah dialami siswa, dan penguatan terhadap diri siswa. Kegiatan tersebut dilakukan pada setiap pertemuan baik di awal, di tengah, maupun di akhir pelajaran. Namun, kegiatan tersebut lebih banyak ditekankan pada awal pelajaran, yaitu pada tahap preparation. Meskipun kegiatan tersebut dilakukan berulang-berulang, tetapi ternyata belum cukup efektif untuk meningkatkan self-esteem siswa. Hal tersebut sesuai dengan pendapat Lawrence (2006, p.28) bahwa proses internalisasi self-esteem membutuhkan waktu yang lama.

\section{Perbandingan Keefektifan Problem-Based Learning dan Pembelajaran Konvensional Ditinjau dari Kemampuan Berpikir Kritis Matematis, Kemampuan Berpikir Kreatif Matematis, dan Self-Esteem}

Hasil uji hipotesis pada kemampuan berpikir kritis matematis diperoleh nilai $z$ sebesar 4,79 yang lebih besar dari $z_{0,05}=1,645$ sehingga $H_{0}$ ditolak. Hal ini berarti pada taraf signifikansi 5\% problem-based learning lebih efektif dibandingkan pembelajaran konvensional ditinjau dari kemampuan berpikir kritis matematis.

Hal tersebut sesuai dengan hasil penelitian Sugandi (2011) yang menyatakan bahwa pada taraf signifikansi 5\% problem-based learning lebih efektif dari pembelajaran konvensional ditinjau dari kemampuan berpikir kritis dan kreatif matematis.

Dilihat dari peningkatan rata-rata kelas problem-based learning memiliki peningkatan yang lebih tinggi dari kelas pembelajaran kon- 
vensional. Hasil ini sejalan dengan hasil penelitian Noer (2009) bahwa peningkatan kemampuan berpikir kritis matematis siswa yang mendapat pembelajaran matematika dengan menggunakan problem-based learning lebih baik daripada siswa yang pembelajaran matematika secara konvensional.

Pada problem-based learning siswa diposisikan sebagai self-directed learner sehingga siswa memiliki peran lebih besar dibandingkan guru dalam hal terjadinya konstruksi pengetahuan pada siswa. Hal tersebut diungkapkan pula oleh Tan (2003, p.22) bahwa problem-based learning di kelas tidak hanya memasukkan masalah, tetapi juga menciptakan kesempatan pada siswa untuk mengonstruksi pengetahuan melalui interaksi yang efektif dan penyelidikan yang kolaboratif.

Hasil uji hipotesis pada kemampuan berpikir kreatif matematis diperoleh nilai $z$ sebesar 5,00 dimana nilai tersebut lebih besar dari $z_{0,05}=1,645$ sehingga $H_{0}$ ditolak. Dengan kata lain, pada taraf signifikansi $5 \%$ problem-based learning lebih efektif dibandingkan pembelajaran konvensional ditinjau dari kemampuan berpikir kreatif matematis.

Hal ini sesuai dengan hasil penelitian Nugroho, Chotim, \& Dwijanto (2013) bahwa problem-based learning lebih efektif untuk mengembangkan kemampuan berpikir kreatif matematis.

Rata-rata peningkatan kemampuan berpikir kreatif matematis siswa kelas problembased learning lebih tinggi dibandingkan kelas pembelajaran konvensional. Hasil ini sesuai dengan hasil penelitian Khoiri (2013) bahwa ratarata peningkatan kemampuan berpikir kreatif siswa kelas eksperimen lebih baik daripada ratarata peningkatan kemampuan berpikir kreatif siswa kelas kontrol.

Pada problem-based learning yang telah dilaksanakan tersedia beberapa masalah yang menuntut siswa menggunakan kemampuan berpikir kreatif matematisnya dalam memecahkan masalah. Masalah tersebut sesuai dengan pendapat Delisle (1997, p.24) bahwa salah satu karakteristik masalah yang baik dalam problembased learning haruslah ill-structured. Hal ini dimaksudkan agar siswa mendapat kesempatan untuk melakukan penyelidikan untuk mendapatkan informasi yang mungkin mengarahkan pada solusi. Siswa terdorong untuk menggunakan informasi yang sudah diketahui dan menemukan informasi tambahan yang diperlukan. Masalah ill-structured juga mengarahkan siswa untuk menemukan sejumlah solusi yang mungkin.

Peningkatan kemampuan berpikir kreatif matematis di kelas pembelajaran konvensional peningkatannya tidak terlalu signifikan karena dalam pembelajaran konvensional siswa tidak diberi kesempatan untuk mengeksplorasi cara atau solusi lain dari yang telah ditemukan sebelumnya. Hal ini juga diungkapkan oleh van de Walle (2007, p.38) bahwa pembelajaran konvensional mengasumsikan siswa memiliki ide yang diperlukan yaitu cara guru berpikir adalah yang terbaik. Siswa terbiasa beranggapan bahwa cara atau jawaban guru-lah yang paling benar. Selain itu, soal-soal yang disajikan dalam pembelajaran konvensional merupakan soal-soal rutin yang mengarahkan pada satu jawaban benar.

Hasil uji hipotesis pada self-esteem diperoleh nilai $z$ sebesar 2,86 yang jauh lebih besar dari $z_{0,05}=1,645$ sehingga $H_{0}$ ditolak. Oleh karena itu, pada taraf signifikansi $5 \%$ dapat dikatakan bahwa problem-based learning lebih efektif dibandingkan pembelajaran konvensional ditinjau dari self-esteem siswa.

Rata-rata peningkatan skor self-esteem siswa pada kelas problem-based learning lebih tinggi dibandingkan kelas pembelajaran konvensional. Hal tersebut mendukung hasil penelitian yang dilakukan oleh Fadillah (2012) yang menyimpulkan bahwa pembelajaran dengan menggunakan masalah terbuka lebih baik dari pembelajaran biasa.

Peningkatan self-esteem siswa di kelas problem-based learning cukup signifikan karena dalam pelaksanaannya peneliti menggabungkan dengan aktivitas yang disarankan oleh Lawrence (2006, pp.87-93) seperti mengekspresikan emosi secara tertulis, mengungkapkan pendapat siswa tentang suatu ekspresi, mengingat kembali kejadian-kejadian yang membuat siswa merasa bahagia, dan memberi afirmasi atau penguatan kepada siswa untuk lebih menghargai dirinya sendiri. Selain kegiatan tersebut, siswa selalu mendapat cerita-cerita sukses seseorang yang kehidupannya tidak sepenuhnya sempurna. Hal ini mendorong siswa menyadari bahwa setiap individu memiliki kelebihan dan kekurangannya masing-masing. Dengan adanya kegiatan-kegiatan tersebut siswa lebih mengenal dirinya serta menghargai keadaan dan apa yang sudah diraihnya saat ini tanpa harus memandang orang lain. Dengan demikian, self-esteem siswa dapat meningkat. Hal tersebut sesuai dengan pendapat Lawrence (2006, p.83) bahwa siswa yang memiliki self-esteem tinggi akan memiliki penerimaan 
diri yang baik, menghormati kebutuhan orang lain, dan memiliki kemampuan untuk berempati.

Pada kelas pembelajaran konvensional, skor self-esteem juga meningkat cukup tinggi. Hal ini dapat disebabkan selama pembelajaran guru menyelipkan nasehat-nasehat yang mengarahkan kepada pendidikan karakter yang sedang digalakkan di sekolah tersebut. Pemberian nasehat tersebut banyak diberikan ketika siswa mengerjakan soal-soal latihan. Pemberian nasehat merupakan salah satu aktivitas yang membangun moral siswa. Akibatnya, self-esteem siswa akan meningkat. Hal tersebut sesuai dengan pendapat Lawrence (2006, p.96) bahwa aktivitas apapun yang dapat membangun moral di sekolah akan dapat meningkatkan self-esteem.

\section{SIMPULAN DAN SARAN}

\section{Simpulan}

Hasil penelitian ini menunjukkan pada taraf signifikansi 5\% dapat disimpulkan bahwa:

Pertama, Problem-based learning efektif ditinjau dari kemampuan berpikir kreatif matematis, tetapi tidak efektif ditinjau dari kemampuan berpikir kritis matematis dan self-esteem siswa.

Kedua, Problem-based learning lebih efektif di-bandingkan dengan pembelajaran konvensional ditinjau dari (a) kemampuan berpikir kritis ma-tematis, (b) kemampuan berpikir kreatif mate-matis, dan (c) self-esteem siswa.

\section{Saran}

Bagi guru atau peneliti yang ingin meningkatkan kemampuan berpikir kreatif matematis dapat menerapkan problem-based learning. Penerapannya dapat dilakukan dengan cara mengintegrasikan tahap-tahap problem-based learning dalam RPP. Namun, untuk dapat meningkatkan kemampuan berpikir kritis matematis dan self-esteem siswa dengan problembased learning guru atau peneliti perlu merancang masalah atau kegiatan yang mengakomodasi seluruh aspek-aspek yang diukur pada setiap pertemuannya.

Tersedianya masalah dalam problembased learning merupakan hal yang sangat penting dan tidak terpisahkan dari bahan ajar. Masalah-masalah kontekstual nonrutin merupakan masalah yang relevan untuk meningkatkan kemampuan berpikir kritis dan kreatif matematis. Masalah tersebut harus dapat memicu konflik kognitif di dalam diri siswa.
Dalam proses memecahkan masalah, pemberian bantuan kepada siswa tidak perlu dilakukan dengan segera agar perkembangan aktual siswa maksimal. Bantuan atau intervensi diberikan ketika benar-benar dibutuhkan oleh siswa.

Dalam upaya meningkatan self-esteem siswa dalam bahan ajar yang dipersiapkan dapat disisipi penguatan self-esteem siswa.

Di kelas, guru memegang peranan yang sangat penting untuk mempengaruhi self-esteem siswa. Peran guru tidak hanya menjaga kualitas hubungan dengan siswa, tetapi juga melakukan serangkaian aktivitas yang dapat meningkatkan self-esteem siswa.

\section{DAFTAR PUSTAKA}

Amsikan, S. (2009). Keefektifan pembelajaran matematika dengan model problembased learning dan model cooperative learning tipe Jigsaw di SMP. Tesis magister, tidak diterbitkan, Universitas Negeri Yogyakarta, Yogyakarta.

Arends, R. I., \& Kilcher, A. (2010). Teaching for students learning: Becoming a accomplished teacher. New York: Routledge.

Coopersmith Self-Esteem Inventory. (1996). Diambil pada tanggal 1 November 2012, dari

https://studentjournals.plymouth.ac.uk/in dex.php/pss/article/ downloadSuppFile/179/42

Delisle, R. (1997). How to use problem-based learning in the classroom. Alexandria: ASCD.

Depdiknas. (2007). Permendiknas Nomor 41, Tahun 2007, tentang Standar Proses untuk Pendidikan Dasar dan Menengah.

Fadillah, S. (2012). Meningkatkan self-esteem siswa SMP dalam Matematika melalui pembelajaran dengan pendekatan open ended. Jurnal Pendidikan MIPA, Vol 13, No 1. Diambil pada tanggal 3 Oktober 2013 dari http://jurnal.fkip.unila.ac.id/index.php/JP M/article/view/398.

Hassoubah, Z. I. (2008). Mengasah pikiran kreatif dan kritis. (Terjemahan Bambang Suryadi). A.S. Noorden. (Buku Asli diterbitkan tahun 2002). 
Ho, B. T. (2004). Teachers as coaches of cognitive process in problem-based learning. Dalam Tan, O. S. (Ed), Enhancing thinking through problembased learning approach (pp 101-115). Singapore: Cengage Learning.

Johnson, E. B. (2002). Contextual teaching and learning. Thausand Oaks, California: Corwin Press, Inc. A Sage Publication Company.

Khoiri, W. (2013). Problem based learning berbantuan multimedia dalam pembelajaran matematika untuk meningkatkan kemampuan berpikir kreatif. Journal of Mathematics Education, Vol 2 No 1. Diambil pada tanggal 3 September 2013 dari

http://journal.unnes.ac.id/sju/index.php/ ujme/article/view/1172.

Krulick, S., \& Rudnick, J. A. (1995). A new sourcebook for teaching reasoning and problem solving in elementary school. Massachusetts: Allyn \& Bacon.

Lawrence, D. (2006). Enhancing self-esteem in the classroom $\left(3^{r d} e d.\right)$. London: Paul Chapman Publishing.

Mullis, I. V. S., et al. (2012). TIMSS 2011 international result in mathematics. Chesnut Hill, MA: TIMSS \& PIRLS International Study Center, Boston College.

Noer, S. H. (2009). Peningkatan kemampuan berpikir kritis siswa SMP melalui pembelajaran berbasis masalah. Makalah disampaikan pada seminar nasional matematika dan pendidikan matematika, di UNY 5 desember 2009, tersedia di http://eprints.uny.ac.id/7048/1/P33\%20D ra.\% 20Sri\%20Hastuti\%20Noer.pdf.

Nugroho, I. A., Chotim, M., \& Dwijanto, D. (2013). Keefektifan pendekatan problem-based learning terhadap kemampuan berpikir kreatif matematik. Journal of Mathematics Education, Vol 2 No 1. Diambil pada tanggal 3 September 2013 dari http://journal.unnes.ac.id/sju/index.php/ ujme/article/view/1201.

Plummer, D. (2005). Helping adolescents and adults to build self-esteem. London: Jessica Kingsley Publishers.

Sugandi, A. I. (2011, November). Pengaruh pembelajaran berbasis masalah dengan setting kooperatif jigsaw terhadap kemampuan berpikir kritis dan kreatif. Disampaikan pada seminar nasional pendidikan MIPA, di Universitas Lampung.

Tan, O. S. (2003). Problem-based learning innovation: Using problems to power learning in the $21^{\text {st }}$ century. Singapore: Cengange Learning.

Van de Walle, J. A. (2007). Elementary and middle school mathematics ( $6^{\text {th }}$ ed.). Boston: Pearson Education, Inc.

Walpole, R. E., et al., (2012). Probability \& Statistic for engineers \& scientists $\left(9^{\text {th }}\right.$ ed.). Boston, MA: Pearson Education, Inc.

Watson, G. H., \& Groh, S. E. (2001). Faculty mentoring faculty: the institute for transforming undergraduate education. Dalam Duch, B. J., Groh, S. E., \& Allen, D. B. (Eds.), The power of problembased learning: a practical "how to" for teaching undergraduate course in any discipline (pp.13-22). Sterling: Stylus Publishing, LLC.

Young, E. L., \& Hoffmann, L. L. (2004). Selfesteem in children: Strategies for parents and educators. Dalam A. S. Canter et. al. (Eds), Helping children at home and school II: Strategies for families and educators (pp 87-89 (S5)). Bethesda, MD: NASP Publications. 